\title{
Clare Gerada: A sense of belonging is vital for doctors
}

\author{
Clare Gerada GP partner
}

Hurley Group, London, UK

In Malta, 21 September is a national holiday. It celebrates the country gaining independence from the United Kingdom in 1964. As well as being British I'm also Maltese, although I've never lived there, and in recent years (no doubt sparked by the trauma of Brexit) I've found myself identifying more with my heritage. I've obtained my Maltese passport and ID card and even gone as far as learning the language, an impossible mix of Arabic and Italian.

This Independence Day, I was surrounded by other Maltese people at a central London hotel owned and run by a Maltese chain, and I felt that I belonged. Not just because the people looked like me (short and dark) or because we shared similar surnames (although Gerada is still uncommon), but because of our many connections. The population of Malta is tiny at around half a million, meaning that, given the large families, almost everyone is connected by family, village of birth, school, or work. Two minutes into a conversation with anyone Maltese you'll find yourself comparing these connections, intensifying the sense of belonging.

The hotel event also made me reflect on how important belonging has been for me in my role as a doctor: having shared experiences and a community behind you is vital for wellbeing. Becoming a doctor is more than just mechanically learning the vast amount of information needed to diagnose and treat disease-it's about becoming one with the profession.

If that sounds like a form of indoctrination, to some extent it is, which can be harmful if it leads to professional stigma around workplace stress or mental illness. However, many customs and practices that have developed over centuries, which doctors become familiar with through their training, also protect us in the job expected of us. From their first day at medical school, students learn these rules of belonging - not in formal lectures, ward rounds, and tutorials but as part of the informal, hidden curriculum that happens in the spaces between.

Doctors' medical identity is immensely strong, both in terms of the individual as a clinician and as a group (medicine), creating a total profession: doctor. The personal and professional become so intertwined that many doctors, even when retired or unable to work, still use the "Dr" title.

Connections and belonging are important, then, for professional survival and mental wellbeing. Sadly, medical training and practice now make it harder to form them, which in my view contributes to the distress we see among doctors.

Just as I've found ways to connect with my heritage in the face of Brexit stress, others in the medical community can do similar. We can, in our own way, all come together to connect with and support each other.

Competing interests: See www.bmj.com/about-bmj/freelance-contributors. Provenance and peer review: Commissioned; not externally peer reviewed. Published by the BMJ Publishing Group Limited. For permission to use (where not already granted under a licence) please go to http://group.bmj.com/group/rights-licensing/ permissions 